\title{
The theory that dare not speak its name: a rejoinder to Mufwene and Francis
}

\author{
Pieter A.M. Seuren \\ Max Planck Institute for Psycholinguistics, P.O. Box 310, 6500 AH Nijmegen, The Netherlands
}

Accepted 29 January 2007

I seem to have made Mufwene and Francis (M\&F; this issue) angry, and perhaps that is just as well, since, as we know, light springs from the shock of opinions. They call my review article on the book they edited "both uninformed and uninformative". Let me start with the latter. The charge of uninformativity is based on the fact that I do not discuss and evaluate each individual contribution as regards its stylistic quality, the adequacy of its contents and the question whether it "aptly reflect[s] the influence of the scholar whose intellectual legacy they wished to celebrate". It is, of course, gratifying to learn what kind of review M\&F wish I had written, but I think I must defend the right of any reviewer to select and highlight one or more specific features of a book under review while justifying that selection. This is precisely what I did in the review article which so enraged M\&F. My critique is chiefly directed at the editorial policy of the editors, Mufwene, Francis and Wheeler, who focused on only one half of McCawley and ignored the other half, while presenting the book as a tribute to the whole McCawley. I criticise that policy because, in my view, the half that was neglected is of far greater importance than the half that was highlighted and because it does an injustice to McCawley and to the discipline of linguistics.

But M\&F go further. They characterize my article as "hardly more than a disparaging commentary on a dead colleague whom he projects as a shadow of himself by the time of his untimely death". In reply I would invite the reader to look again at my review (Seuren, 2006), where I amply praise McCawley for his innovative, even visionary, contributions and his profound insights, which are commented on at length. I also criticise him for yielding to sociological pressure, with the result that he did not follow up on these insights by seeking stronger formal and empirical support in cases where that was needed and did not capitalize on that support when it was offered by others. A "disparaging commentary on a

E-mail address: pieter.seuren@mpi.nl 
dead colleague"? Or a realistic assessment made after the untimely demise of a much admired colleague who was also a good friend?

Significantly, M\&F make no mention of the sociological factor that plays such a prominent role in the review they object to so angrily. "Significantly", because the editorial policy followed by M\&F (and the third editor) is a direct consequence of the greatest scandal in twentieth-century linguistics, the character assassination of Generative Semantics by Chomsky and his school. The result of this systematic and persistent campaign to vilify, without benefit of academic argument, a theory with enormous potential has been that Generative Semantics became, to adapt Oscar Wilde, the theory that dare not speak its name. And indeed, as I point out in my review, in only one of the twenty-two contributions - one that I comment on favourably - is Generative Semantics actually mentioned by name, and that only once. In the editorial texts, Generative Semantics is referred to seven times, but always with apparent discomfort. Three times it is, puzzlingly, condemned for being "abstract". It is perfectly clear from my review that I chose to focus on the campaign against Generative Semantics because of its all-pervasive and highly negative effects in the discipline. That M\&F refrain from commenting on this aspect, both in their editorial commentaries in the book reviewed and in their reply to my review, suggests a deep embarrassment on their part.

This brings me to their charge of uninformedness. M\&F claim that there is no divide between the earlier and the later McCawley: "we argue that McCawley's later work did in fact build on his earlier ideas in a principled manner". Leaving aside his contributions to phonology, which have nothing to do with Generative Semantics, their argument is unsuccessful. McCawley's earlier work was a systematic investigation of the consequences and empirical tenability of the theoretical principles underlying Generative Semantics, which had been partly formulated by him. This stopped abruptly in the late 1970s, after which time he gave up this activity altogether, sometimes even revoking without argument views he had developed and convincingly propounded in his better days. I have no difficulty agreeing with $\mathrm{M} \& \mathrm{~F}$ when they say that many aspects of McCawley's later work "clearly reveal his Generative Semantics background", but this work sadly fails to exhibit the "principled manner" in which they claim McCawley elaborated his earlier ideas. From the late 1970s onwards he rang certain changes on old themes (but not "in a principled manner"), and when he looked at other things he was no longer driven by his earlier, sparkling, ideas. I can understand why M\&F don't want to recognize this: if they did, it would amount to an admission that their editorial policy for a festschrift bearing the subtitle Jim McCawley's Legacy was basically flawed because it distorts a relevant part of the history of linguistics.

A last word about F\& M's vexations regarding eclecticism. For the way they read the concept "eclectic" I would prefer terms like interdisciplinary or undogmatic, and I have no problem with a theory, or a researcher, being both. On the contrary, interdisciplinarity is a jewel in the crown of science, and transcending dogmas is one mark of a creative mind. In fact, in his younger years McCawley excelled in both these qualities, in that he brought formal logic into linguistics (perhaps a trifle too "abstract" for the editors?) and was ever happy to trample on dogmas of any kind, including those current in logic.

Eclecticism is a different matter. As one reads in the famous 1911 edition of the Encyclopaedia Britannica, "[e]clecticism always tends to spring up after a period of vigorous constructive speculation, especially in the later stages of a controversy between thinkers of pre-eminent ability.... [E]clecticism in the sphere of abstract thought is open to this 
main objection that ... the combination of principles from hostile theories must result in an incoherent patchwork. ... It is in practical affairs that the eclectic or undogmatic spirit is most valuable, and also least dangerous." If we take the term constructive speculation to cover the development and testing of fruitful scientific hypotheses, then McCawley clearly did not suffer from "eclectic" tendencies in his early work, in the sense of this text. For if he had, Generative Semantics would have run the risk of being "an incoherent patchwork" - an aspersion which not even Newmeyer ever cast upon it. Was McCawley an "eclectic" in his later years? Perhaps one can call him that, but I rather feel that he had become a theoretical sceptic, no longer caring much about a coherent theory, and had persuaded himself that anything that looked like a bright idea would do-much in Feyerabend's spirit. This sentiment was overtly expressed in the quixotic title of his 1982 book Thirty Million Theories of Grammar, a collection of articles written during the mid and late 1970s where he proposed solutions for syntactic problems which he now claimed allowed for literally thirty million different underlying theories.

In their final paragraph M\&F write: "Part of the message we get from Seuren's essay seems to be that McCawley, especially the later one, does not deserve a memorial Festschrift." This, I am sorry to say, is unfair. I would have thought that the early, vintage, McCawley deserved a ringing memorial tribute, which I would have been happy to review in every detail. Unfortunately, however, he did not get one, and we all know why. And as for the later McCawley, well, who would begrudge him a memorial volume! But that would have to be presented explicitly as a tribute to the later McCawley, and not as a celebration of his total legacy. And it would not have been a book that I would have wished to review in the way $\mathrm{M} \& \mathrm{~F}$ expect books to be reviewed.

\section{References}

McCawley, J.D., 1982. Thirty Million Theories of Grammar. The University of Chicago Press, Chicago.

Mufwene, S.S., Francis, E.J., 2007. McCawley's legacy: A response to Pieter A.M. Seuren. Language Sciences, this volume, doi:10.1016/j.langsci.2006.09.002.

Seuren, P.A.M., 2006. McCawley’s legacy. Language Sciences 28 pp. 521-526. 